\title{
Correction: Integrated control of Aedes albopictus in Southwest Germany supported by the Sterile Insect Technique
}

Norbert Becker ${ }^{1,2,4^{*}}$ (D) , Sophie Min Langentepe-Kong ${ }^{1}$, Artin Tokatlian Rodriguez ${ }^{4}$, Thin Thin Oo ${ }^{2,3}$, Dirk Reichle ${ }^{3}$, Renke Lühken ${ }^{5}$, Jonas Schmidt-Chanasit ${ }^{5,6}$, Peter Lüthy ${ }^{7}$, Arianna Puggioli ${ }^{8}$ and Romeo Bellini ${ }^{8}$

\section{Correction to: Parasites \& Vectors (2022) 15:9} https://doi.org/10.1186/s13071-021-05112-7

Following publication of the original article [1], the authors flagged an error in one of the values provided in the Methods subsection 'Quality control of the sterile Ae. albopictus males': where it should say "at $25 \pm 2{ }^{\circ} \mathrm{C}$, it said "at $252^{\circ} \mathrm{C}$ ".

The published article has since been corrected.

\author{
Reference \\ 1. Becker N, Langentepe-Kong SM, Tokatlian Rodriguez A, Oo TT, Reichle \\ D, Lühken R, Schmidt-Chanasit J, Lüthy P, Puggioli A, Bellini R. Integrated \\ control of Aedes albopictus in Southwest Germany supported by the \\ Sterile Insect Technique. Parasites Vectors. 2022;15:1-19. https://doi.org/ \\ 10.1186/s13071-021-05112-7.
}

\section{Publisher's Note}

Springer Nature remains neutral with regard to jurisdictional claims in published maps and institutional affiliations.

\begin{abstract}
Author details
${ }^{1}$ Faculty of Biosciences, University of Heidelberg, Im Neuenheimer Feld 230, 69120 Heidelberg, Germany. ${ }^{2}$ Institute of Dipterology (IfD), Georg-Peter-Süß-Str. 3, 67346 Speyer, Germany. ${ }^{3}$ Kommunale Aktionsgemeinschaft zur Bekämpfung der Schnakenplage e.V. (KABS), Georg-Peter-Süß-Str. 3, 67346 Speyer, Germany. ${ }^{4}$ IcyBac-Biologische Stechmückenbekämpfung GmbH (ICYBAC), Georg-Peter-Süß-Str. 1, 67346 Speyer, Germany. ${ }^{5}$ Department of Arbovirology, Bernhard-Nocht-Institute for Tropical Medicine, Bernhard-Nocht-Str. 74, 20359 Hamburg, Germany. ${ }^{6}$ Faculty of Mathematics, Informatics and Natural Sciences, Universität Hamburg, Ohnhorststrasse 18, 22609 Hamburg, Germany. Institute of Microbiology, Swiss Federal Institute of Technology (ETH Zürich), Vladimir-Prelog-Weg 1-5/10, 8093 Zürich, Switzerland. ${ }^{8}$ Centro Agricoltura Ambiente "G. Nicoli" (CAA), Via Sant'Agata 835, 40014 Crevalcore, Italy.
\end{abstract}

Published online: 18 February 2022

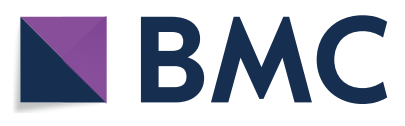

(c) The Author(s) 2022. Open Access This article is licensed under a Creative Commons Attribution 4.0 International License, which permits use, sharing, adaptation, distribution and reproduction in any medium or format, as long as you give appropriate credit to the original author(s) and the source, provide a link to the Creative Commons licence, and indicate if changes were made. The images or other third party material in this article are included in the article's Creative Commons licence, unless indicated otherwise in a credit line to the material. If material is not included in the article's Creative Commons licence and your intended use is not permitted by statutory regulation or exceeds the permitted use, you will need to obtain permission directly from the copyright holder. To view a copy of this licence, visit http://creativecommons.org/licenses/by/4.0/. The Creative Commons Public Domain Dedication waiver (http://creativeco mmons.org/publicdomain/zero/1.0/) applies to the data made available in this article, unless otherwise stated in a credit line to the data. 